\title{
The Ruqyah Syar'iyyah Spiritual Method as an Alternative for Depression Treatment
}

\author{
Afifuddin, M.M. \\ Corresponding Author, Advance Medical and Dental Institute (AMDI), USM and UTM Perdana School \\ Email:drafifuddin@gmail.com \\ Nooraini, 0. \\ UTM Perdana School, Universiti Teknologi Malaysia, Jalan Sultan Yahya Petra, 54100 Kuala Lumpur, Malaysia \\ Email: p-noraini@utm.my
}

\section{Doi:10.5901/mjss.2016.v7n4p}

\section{Abstract}

This paper aims for an in-depth discussion of the Islamic spiritual method known as the ruqyah syari'yyah, an increasingly popular method used to treat depression. Ruqyah is a spiritual treatment process based on methods that are in line with other religious practices such as prayer and zikr (divine remembrance). The objective of this study is to identify the health level of research subjects before and after ruqyah spiritual treatments. Research was conducted for this study using qualitative methods that combined interview and observation. The degree of depression of the subject was determined using the Beck Depression Inventory (BDI). The study was carried out involving two subjects experiencing serious degrees of depression that are marked as subjects $X$ and $Y$, who received scores of 60 (extreme depression) and 56 (extreme depression). After ruqyah syar'iyyah spiritual treatment was given, subjects $X$ and $Y$, respectively, obtained scores of 10 (normal) and 8 (normal). The findings of the study are expected to educate the public about correct Ruqyah syar'iyyah spiritual treatment methods, and to encourage an understanding of the development of alternative treatments that can produce therapeutic effects for people with mental depression.

Keywords: Ruqyah; Depression; Therapeutic; Alternative; Islamic spiritual method

\section{Introduction}

Therapeutic treatments based on the use of spiritual methods are gradually developing in various parts of the world (Krycka, 2000). These developments have led to the conviction that spiritual elements are capable of producing therapeutic effects on humans, especially on patients who suffer from mental problems (Krycka, 2000). Religion is a component that is often associated with spiritual elements (Al-Ghazali, 1987; Koenig, 2002; Khadher Ahmad, 2012). With the implementation and the practices of religion, the spiritual element can be expressed and can produce good therapeutic effects (Said Hawwa, 1999; Koenig, 2001). Koenig (2002) outlined several reasons why medical practitioners should emphasise the need for religion in obtaining the spiritual welfare of mankind. First, most patients profess a religion, thus their belief in religion can help in overcoming the problem (Jawziyyah, 1999). Second, religious beliefs influence decisions regarding treatment, especially when patients are facing serious health problems (Haron Din, 2012; Wahid Bali, 2007; Amran Kasimi, 2009). Third, religious activities can contribute to improved quality of life and health (Jawziyyah, 1999). Fourth, most chronic patients require doctors who are able to meet their spiritual needs through religion. Finally, doctors fulfilling the spiritual needs of their patients are not something new; there is an established history of doctors or practitioners linking religion and medicine in the health care process. Therefore, when a medical practitioner ignores the spiritual elements of religious practice, it is tantamount to the abandonment of the overall health of the patient (Koenig, 2002). According to Kurtz and Ketcham (2002), spiritual elements exist and are some of the defining elements of human existence. We do not determine the spiritual element; these elements define us (Kurtz and Ketcham, 2002). When we try to define the spiritual element we may not be able to define its limit, but in the process of understanding the spiritual we can understand ourselves (Kurtz and Ketcham, 2002). Therefore, in Islam, the understanding of the spiritual elements must be referred to religion through the use of Al-Quran and Sunnah as sources. (Said Hawwa, 1999). The Muslim scholar Al-Ghazali (1987) describes the spiritual element as pertaining to the 'ruh' (soul). The element of the ruh is latifah (tender) and delicate, and, through it, humans can grasp and understand. This element of ruh is something miraculous that comes from God; therefore, it cannot be comprehended solely by the 
intellect. This tender and delicate component has a relationship with aqal (mind), nafs (self), and the heart.

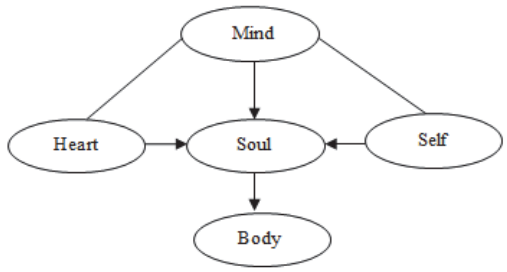

Figure 1: The links between the Mind, the Heart, and the Self as well as the Soul According to Al-Ghazali (1993), Said Hawwa (2010)

Based on the above figure 1, the Islamic scholar Said Hawwa and Al-Ghazali has linked various human dimensions that affect the body, including the dimensions of mind, nafs, heart, and spirit. The power and the goodness of the body depend on the soul, which affects the other three elements, namely mind, self, and heart. If the soul is good then the mind, the self, and the heart will also be good. Hence, in Islam there is a spiritual treatment method used for treating the internal soul, known as ruqyah syar'iyyah, to increase physical, mental, social, and spiritual welfare. Thus, by means of ruqyah syar'iyah, therapeutic effects ameliorate mental depression, which is related to the mental component of the human internal soul (Dogan, 1997; Abdullah,1998; Adib 2004) .

This research aims to examine how treatment based on Islamic spiritual treatment may become a fundamental rehabilitation process for patients who suffer from mental depression. The contribution of this study will be in two aspects: the first is to analyse the potential of spiritual care in treating depression, and the second is to evaluate the effectiveness of ruqyah syar'iyyah treatment in mental depression and personality change.

\section{Research Methods}

This study employs a qualitative approach, focusing on qualitative approaches that involve library research and field studies (inventories, observation and interviews). Case study was used in this research. According to Yin (2009), case study would be a suitable method to be employed in a real case. Further more, the usage of case study has great contributions in the field of medicine, psychiatry, social work and psychology. Thus, this research fulfils the stated criteria. Inventories: This research applied the Beck Depression Inventory (BDI) to measure a subject's depression level. This inventory method has a high reliability, with a Cronbach's alpha 0.83. Through this inventory, several depressive symptoms can be categorised and assessed according to their respective levels: extreme depression (BDI score 40-63); severe depression (BDI score 31-40); mild depression (BDI score 21-30); borderline clinical depression (BDI score 1720); depression (BDI score 11-16); and Normal (BDI score 1-10). BDI has data reliability and validity that reveal internal consistency between $0.73-0.92$ with alpha coefficients for both depression and non-depression subjects, at 0.86 and 0.81, respectively (Beck et al., 1993).

Table 1: Beck's Inventory Distribution of Questions According to Symptoms of Depression

\begin{tabular}{|c|c|c|c|c|}
\hline Num & & Symptoms & Item & Number of Items Involved \\
\hline 1 & Physiology & $\begin{array}{l}\text { Loss of appetite, disturbed sleep, weight loss, impaired } \\
\text { physical health, sexual disturbance }\end{array}$ & $\begin{array}{c}16,18 \\
19,20,21\end{array}$ & 5 \\
\hline 2 & Affective & Frustration and sadness & 1,7 & 2 \\
\hline 3 & Cognitive & $\begin{array}{l}\text { Regrets, loss of focus, despair, feeling punished, loss of } \\
\text { interest, feeling bad, feeling betrayed, feeling suicidal, sense } \\
\text { of failure, guilt }\end{array}$ & $\begin{array}{c}2,3,4,5,6,8,9 \\
12,14,15\end{array}$ & 10 \\
\hline 4 & Personality & Tiredness, difficulty in making decision, crying, irritability & $\begin{array}{l}10,11 \\
13,17\end{array}$ & 4 \\
\hline
\end{tabular}

Through observation, the implementation of this method is carried out during ruqyah treatment sessions conducted on subjects who suffer from depression. This treatment was conducted by experienced Muslim practitioners in ruqyah syar'iyyah spiritual treatment. Semi-structured interviews were carried out before the treatment and two weeks after the 
treatment was conducted. The findings were analysed through deductive and inductive methods. Observation: Observation method is a method implemented to see how the subject reacted to the treatment. Through this approach, researchers can assess the diversity of subject reactions before, during, and after ruqyah treatment. In addition, this observation method allows researchers to determine depressive symptoms as they manifest physically through displays of grief, physical pain in the body, disappointment, and others. Interview: As noted, data were collected from various sources. The main source of data collection was from the semi-structured interviews.

The sampling technique known as purposive sampling was used in the process of data collection. The subjects were selected from participants who came for the ruqyah syar'iyyah spiritual treatment at the Islamic treatment centre after using allopathic treatment for a considerable period, and were confirmed by doctors as having depression. A total of 2 subjects were tested using this ruqyah syar iyyah method. One male subject and one female subject, who were both Malay and Muslim, were marked as subject $X$ and subject $Y$, respectively. Both subjects had been diagnosed by doctors to suffer from depression and had been given olanzapine $5 \mathrm{mg}$ to treat this problem. The female subject was a businesswoman who had been suffering from depression for 5 years and was reliant on the medication. The male subject, on the other hand, was a secondary school counselling teacher who had suffered from depression for a year. This study examined the two subjects that were tested with ruqyah spiritual treatment for the purpose of treating depression.

Among the methods used by practitioners of ruqyah for the depressed subject were putting their hands on certain parts of the subject's body that were identified as problematic. For patients of depression, the specific parts of the body that are touched when the verses of ruqyah syar'iyyah are recited are the head, back, neck, stomach, and several other spots. The combination of the verses was also recited over water with the intention of asking Allah to cure the illness; the subject should then drink the water. The subject was supplied with specific ruqyah verses to be recited on their own. In this phase, the observation made by the researchers was to assess the responses that occurred when subjects were treated. Immediately after the treatment session, the subjects were interviewed and given a set of ruqyah practices and verses that needed to be practiced in their homes. The subjects were asked to come again after two weeks for diagnosis during which a second interview was conducted. After the second interview, the practitioner determined whether the subject should seek medical follow-up, depending on the degree of depression that had been measured as well as the response to the treatment. Data Analysis: Researchers used thematic analysis to analyse all the findings from data collection.

\section{Results and Discussion}

After the process of encoding and consensus, both subjects were evaluated and analysed according to three categories: (1) Subject's medical history; (2) Positive changes in symptoms of depression; and (3) Treatment. The particulars that have been recorded are as follows.

\subsection{Subjects' Medical History}

\subsubsection{Subject $X$ :}

Subject $X$ suffered severe pain in the back and abdomen and often experienced numbness and severe itching. The subject had sought modern treatment due to high blood pressure that was so extreme that it was immeasurable, along with extremely low blood pressure and a brain tumour. Subject $X$ had received modern treatment from various government and private specialist hospitals and clinics and was given sedative medication (Olanzapine) due to unstable emotions and hallucinations. The subject also often fainted, cried for no apparent reason, and felt that life was useless. This occurred over a span of 5 years between 2009 until 2014.

In 2011, the medical officer in a private specialist hospital confirmed that the subject had a brain tumour that needed to be removed surgically. Considering the possible complications, the subject decided not to undergo surgery but decided instead to seek treatment at several Islamic treatment centres.

Subject X: ... "The pain I have been having has lasted for quite a while especially in the head, abdomen and back. I often faint regardless of the time. Apart from that the specialist doctor has confirmed that I have a growth in the brain and has advised me to have it removed as it has grown. The doctor explained that if it is not removed it will affect my vision. The rate of my blood pressure has also reached a point where the instrument that measures blood pressure was unable to measure the rate of my blood."

Apart from physical problems, subject $X$ also experienced strong emotional disturbances. The description from 
subject $X$ was as follows:

Subject $X:$... The drastic emotional changes that I have experienced happened almost 3-4 years ago. They happened without me realising it. I was often depressed with the reports I received from doctors as I was very sick and my work productivity had decreased. Plus the troubling emotions and feelings. The situation was made worse by the hallucinations that often affected me."

\subsubsection{Subject $Y$ :}

Subject $Y$ has suffered from vertigo and was supplied with vertigo medication to overcome dizziness; the subject had also undergone a blood test. Subject $Y$ was a teacher and often had to be carried by students and teachers while teaching at school. Subject $Y$ claimed that he often saw an alien creature at his home with an ugly face. He also claimed to have accidentally punched his wife's face and broken her upper lip due to the disturbance caused by that creature. He had lost weight, dropping from $96 \mathrm{~kg}$ to $86 \mathrm{~kg}$. Strangely, even a full body check-up revealed nothing wrong, which led him to seek alternative treatments for his sickness. Apart from physical problems, subject $Y$ also suffered from depression. The description from subject $Y$ was as follows:

Subject Y: "Since a year ago I have been experiencing drastic emotional changes, even while not doing anything. I feel like dying, I cry without reason, I feel that living has no longer any use to me, I have lost my appetite, have less sexual desire; my body weight went down $10 \mathrm{~kg}$, from $96 \mathrm{~kg}$ to $86 \mathrm{~kg}$, and more..."

After examining the medical history of subject $X$ and subject $Y$, the process of identifying the symptoms of depression was continued to the second category, which was the positive changes from symptoms of depression.

\subsection{Positive Changes in Symptoms of Depression}

Subjects $X$ and $Y$ have received treatment 3 times; depression symptoms which involve personality, physiology, cognitive and affective have decreased dramatically. According to subjects $X$ and $Y$, both felt a positive change from the symptoms that were mentioned during the first interview with researchers. The depression scale that was recorded was based on the items personality, affective, cognitive, and physiology according to BDI, as follows:

Table 2: Positive Changes in Symptoms of Depression

\begin{tabular}{|c|c|c|c|c|c|}
\hline Bil & $\begin{array}{c}\text { Type of } \\
\text { Subject }\end{array}$ & $\begin{array}{c}\text { Before Ruqyah } \\
\text { Treatment }\end{array}$ & $\begin{array}{c}\text { Post-test 1: } \\
\text { Two weeks after the } \\
\text { first treatment }\end{array}$ & $\begin{array}{c}\text { Post-test 2: Two weeks after } \\
\text { the treatment of post-test one }\end{array}$ & $\begin{array}{c}\text { Post-test 3: Two weeks after } \\
\text { the treatment of post test-two }\end{array}$ \\
\hline 1 & Subject X & $\begin{array}{c}60 \\
\text { (Major Depression) }\end{array}$ & $\begin{array}{c}52 \\
\text { (Major Depression) }\end{array}$ & $\begin{array}{c}23 \\
\text { (Mild depression) }\end{array}$ & $\begin{array}{c}10 \\
\text { (Normal) }\end{array}$ \\
\hline $\mathbf{2}$ & Subject Y & $\begin{array}{c}56 \\
\text { (Major Depression) }\end{array}$ & $\begin{array}{c}38 \\
\text { (Major Depression) }\end{array}$ & 8 & 8 \\
(Normal) & (Normal) \\
\hline
\end{tabular}

To conclude, both subjects sensed the change and the reduction of depressive symptoms after several treatment sessions of ruqyah syar'iyyah. In fact, according to subject $X$, she is no longer taking olanzapine after a number of ruqyah syar'iyyah treatment sessions. After examining the depression scale before and after the ruqyah syariyyah treatment, we examine the implications of this pattern of response to treatment.

\subsection{The Implications of the Ruqyah Treatment}

Subjects $X$ and $Y$ experienced changes in their physical and mental aspects after going through this treatment. The reduction in physical and mental pain was acknowledged by the subjects. Their responses were recorded as below:

Subject X: "After several treatments, I felt very, very different ...the extreme pain in my body is gone ... I was surprised at the confirmation that the tumour in my brain was $100 \%$ gone...Subhanallah (Praise be to God).... The emotional distractions that I had felt, such as feeling suicidal, sadness, disappointment with life, difficulty in sleeping, loss of appetite, hallucinations, often seeing things that should not have been seen have decreased dramatically. Apart from that I found that this ruqyah method is very efficient. My brain tumour is completely gone, my health has improved, my emotions are stable and I am no longer hallucinating and I feel very calm now compared to before. And several 
improvements that can be done are that the practitioner should not press too strongly on the body, as it was painful."

Subject Y: "Alhamdulillah (Thank God) with Allah's permission, I can feel very significant changes. I have experienced extraordinary physical and emotional changes. The pain in parts of my body, especially in the head and stomach, has been reduced. My emotions are more stable now, and I am feeling calmness like used to from a year ago before I started having those emotional disturbances. During the treatment, especially when the practitioner was touching the painful parts of my body and reciting the ruqyah verses, I felt as though there was a power that was helping me to heal. The painful parts of my body have decreased in pain and the irritation of the body that I was experiencing has significantly reduced. Another thing is that when I sincerely practiced the practices recommended by the practitioner, I really felt the tranquillity, and I was no longer feeling the dizziness and stomach pain that used to interfere with my life".

Conclusively, both subjects $X$ and $Y$ acknowledged the physical and emotional changes after undergoing the ruqyah syar'iyyah treatments.

\section{Discussion and Conclusion}

This study has revealed that ruqyah syar iyyah treatment methods can be used as an alternative treatment to provide relief for mental health ailments, particularly depression. The results show a significant interrelation between religious activity (ruqyah syar'iyyah) and internal and spiritual elements. As such, the development of spiritual elements through stimulation of the religious element has been recognized to be effective as a therapeutic element by previous studies. Among them are the studies of York, C. M. (2011). Those findings showed that the element of ruqyah sar'iyyah provided a therapeutic effect to two counsellors who were suffering from ureter infection and extreme sadness due to the death of loved ones. The model by Jones (2004) on the impact of religion on health stated that a) practical religious practices are able to produce a therapeutic effect on health; these activities are prayers, self-examination, and meditation; b) religion is also able to prevent people from engaging in unhealthy activities that can affect health; and c) for those who practice religion, it will increase their social support and will be able to produce a positive reaction from the physical and psychological aspects compared with those who do not practice a religion. The study conducted by Jones was further confirmed by research conducted by Koenig (2001) through the Bio-Psycho-Social Health Model. In this model, three related elements were presented which provide a therapeutic effect: 1) belief in religion; 2) religious practices; and 3) society. This model explained that obeying religious instructions, as well as practicing the religion with sincere faith, will produce therapeutic effects to the society in various aspects. Koenig's Model is as follows:

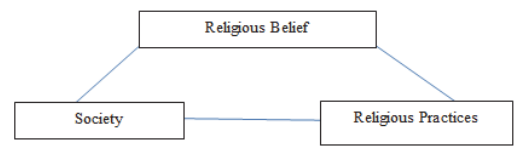

Figure 2: Adapted from the Influence of Religious Belief and Bio-Psycho-Social Health

Studies by York (2011), Jones (2004) and Koenig (2001) support this study where it demonstrates that religious activities used to treat patients with depression produce positive results. This is apparent from subjects $X$ and $Y$, who experienced a decrease in their depression, which was at an alarming level prior to treatment. This study is further supported by Ganzini et al (1998). According to that research, belief in religion at the highest level of faith can provide a positive clinical effect on patients in terms of personality and actions. It is also able to minimize the risk of getting sick (Lammer, et al, 2000), and at the same time can aid patients in reducing emotional stress and anxiety. This study also exposes a potential alternative for people seeking treatment, and to prevent involvement with treatments that are against Islam, such as black magic. The positive changes in terms of the physical and psychology after practicing the verses and acts of ruqyah syar'iyyah have also enabled the subjects to be healthy members of the society.

In conclusion, ruqyah syar iyyah, as practiced by Muslim practitioners with the aim of treating depression, has the potential to become a new alternative to the modern treatment locally and globally. The use of correct treatment methods that are based on trust in Allah as the healer are a strong foundation for recovery in this therapeutic treatment.

\section{Acknowledgements}

This research is sponsored by Advance Medical and Dental Institute, Universiti Sains Malaysia Pulau Pinang, Malaysia and Universiti Teknologi Malaysia (UTM). 


\section{References}

Al-Ghazali, Abu Hamid Muhammad Ibn Muhammad (1993). The Revival of the Religious Sciences. Edited by al-Imam Al-Hafiz Al-Iraqi, Beirut: Dar Al-Khayar

Adib, S. (2004). From the biomedical model to the Islamic alternative: A brief overview of medical practices in the contemporary Arab world. Social Science and Medicine. 58:4: 697-702

Amran Kasimin (2009). A Magic of spiritual practice, Selangor: Penerbit Universiti Kebangsaan Malaysia : Malaysia, 55

Bali, Wahid Abd Salam (2007). The cutting edge : how to face evil sorcerers, Misr :Dar al-Ghad al-Jadid, 102

Dogan, M. (1997). The effects of prayer on psychology and psychotherapy. Unpublished doctoral dissertation, Cumhuriyet University, Sivas, Turkey

Haron Din (2012). Introduction to Islamic Medical, Selangor, Persatuan Kebajikan dan Pengubatan Islam Darulsyifa, 10

Humud, Mahmud Qassim (2001). Magic and sharia law: Developments and how to handle. Umman al- Urdun, Dar Wa'il li al-Tiba' wa alNash.

Jawziyyah, I. (1999). Healing with the medicine of the prophet (Jalal Abu al-Rab, Trans., \& Abdul R. Abdullah, Ed.). Riyadh, Saudi Arabia: Darussalam

Jones J.W (2004). Religion, Health And The Psycology Of Religion: How Research On Religion And Health Helps UnderstandReligion". Journal Religion and Health, 43, 4, 318

Krycka, K. (2000). Shamanic Practices and the Treatment of Life-Threatening Medical Conditions. Journal of Transpersonal Psychology, 32,1, 69-87.

Koenig, H.G. (2001). Handbook of Religion and Health. New York: Oxford University Press

Khadher Ahmad (2012). Analysis of hadiths in the Kutub al-Sitta: Application of Islamic Treatment Centre. Thesis Doctor of philosophy, Universiti Malaya

Lammer, C., Ireland, M,. Resnick, M. et al. (2000). Influence of adolescent decision to pospone onset sexual intercouse: A survival Anaysis of virginity among youth ages 13 to 18 years, Journal of adolesent health, 26, $42-48$

Sa'id Hawwa (2010). Spiritual education (ter) Siddiq Fadzil, Kuala Lumpur: Mutiara ilmu Selekta, 47

Yin, R. (2009). Case study research: Design and methods (4th ed.). Thousand Oaks, CA: Sage

York, C. M. (2011). The effects of ruqya on a non-muslim: a multiple case study exploration", PhD Thesis Institute of Transpersonal Psychology Palo Alto, California, Amerika Syarikat. 